\title{
触 New Disease Reports \\ First report of Moniliophthora roreri causing frosty pod rot on Theobroma cacao in Jamaica
}

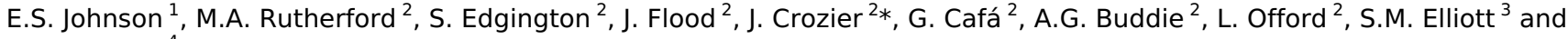 \\ K.V. Christie ${ }^{4}$ \\ ${ }^{1}$ Inter-American Institute for Cooperation on Agriculture (IICA), Hope Gardens, Kingston 6, Jamaica; ${ }^{2}$ CABI, Bakeham Lane, \\ Egham, Surrey, TW20 9TY, United Kingdom; ${ }^{3}$ Ministry of Industry, Commerce, Agriculture \& Fisheries, Bodles Research \\ Station, Old Harbour, St. Catherine, Jamaica; ${ }^{4}$ Ministry of Industry, Commerce, Agriculture \& Fisheries, Plant Quarantine \& \\ Produce Inspection, Hope Gardens, Kingston 6, Jamaica
}

*E-mail: j.crozier@cabi.org

Published: 18 Jul 2017. Keywords: Caribbean, cocoa, fungal disease

Frosty pod rot (FPR), caused by the basidiomycete Moniliophthora roreri, is a devastating disease of cacao. First discovered in Ecuador in 1917, FPR is present in the main cacao producing countries of Southern and Central America, except Brazil (López \& Enríquez, 1980; Evans, 2016) but it has not been previously reported in the Caribbean. In August 2016, unusual symptoms were observed on cacao pods on farms in Crooked River located in the parish of Clarendon in Jamaica. Examination of affected pods and fungal spores by officers of the Research and Development Division (Ministry of Industry, Commerce, Agriculture and Fisheries) led to a tentative diagnosis of FPR.

Following this discovery, infected pods were dispatched to the CABI Diagnostic and Advisory Service, Egham, United Kingdom for examination and analysis. Symptoms typical of FPR (Evans, 1981) were observed, namely necrotic lesions, white fungal mycelium and cream/beige sporulation on the pod surface (Fig. 1) along with extensive brown necrosis of the internal pod tissues (Fig. 2). Spore samples were removed from the surface of pods with a sterile needle and tissue samples aseptically excised from both the surface tissues and internal pod tissues. Samples were plated on tap water agar, potato dextrose agar (PDA) and 2\% malt extract agar (MEA) and incubated at $25^{\circ} \mathrm{C}$. Emergent fungal colonies were purified by sub-culturing. Morphological characteristics of sporulating fungal colonies on MEA and PDA after 5 to 7 days growth were indicative of those of $M$. roreri as described previously (Evans, 1981).

DNA was extracted from selected colonies using MicrolysisPlus (Microzone Ltd, UK), amplified by PCR, purified and sequenced on the AB3130 Genetic Analyzer (Applied Biosystems, USA). For cultures derived from spore samples, the internal transcribed spacer and large subunit regions of the rDNA were amplified with primer pairs TW81/AB28 (Curran et al., 1994) and NL1/NL4 (Kurtzman \& Robnett, 1997), respectively. For cultures derived from pod tissues, the translation elongation factor region was amplified using primer pair EF1T/EF2T (O'Donnell \& Cigelnik, 1997). Comparison of resulting sequences with representative sequences available in the 'Fungi' database of the European Molecular Biology Laboratory European Bioinformatics Institute using the FASTA algorithm confirmed the presence of $M$. roreri in cultures derived from all spore and tissue (99-100\% homology). Two isolates were deposited in the CABI Genetic Resources Collection as IMI506582 and

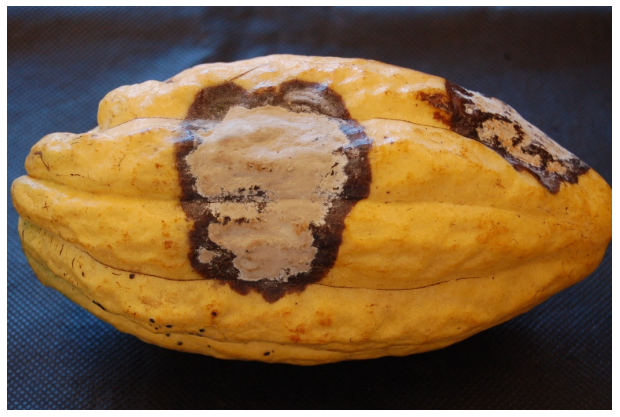

Figure 1

To cite this report: Johnson ES, Rutherford MA, Edgington S, Flood J, Crozier J, Cafá G, Buddie AG, Offord L, Elliott SM, Christie KV, 2017. First report of Moniliophthora roreri causing frosty pod rot on Theobroma cacao in Jamaica. New Disease Reports 36, 2. http://dx.doi.org/10.5197/j.2044-0588.2017.036.002 (C) 2017 The Authors

This report was published on-line at www.ndrs.org.uk where high quality versions of the figures can be found.

IMI506584. Reference sequences were deposited in Genbank as Accession Nos. MF139030 (IMI506582), MF139031 (IMI506584), MF139032, MF139033 and MF139034.

Fine flavour cocoa is one of Jamaica's traditional export crops with an estimated 11,000 smallholders producing cacao commercially on holdings of less than 2 hectares. It is an important cash crop for farming communities in rural Jamaica as more than a quarter of the population in the cacao-producing parishes are living below the national poverty line. In 2016, Jamaica exported over USD 1.4 million in cacao and derivatives, which represents a significant source of income for cacao farmers. More than half of the cacao produced in Jamaica comes from Clarendon Parish and as such FPR will have a devastating impact. Efforts are underway to determine extent of the spread of the disease in Clarendon and surrounding parishes in an effort to isolate and manage it with a view to eradication. This is the first confirmed report of FPR on cacao in the Caribbean.

\section{References}

Curran J, Driver F, Ballard JWO, Milner RJ, 1994. Phylogeny of Metarhizium: analysis of ribosomal DNA sequence data. Mycological Research 98, 547-552. http://dx.doi.org/10.1016/S0953-7562(09)80478-4 Evans HC, 1981. Pod rot of cacao caused by Moniliophthora (Monilia) roreri. Phytopathological Papers 24, 44.

Evans HC, 2016. Frosty pod rot (Moniliophthora roreri). In: Bailey BA, Meinhardt LW, eds. Cacao Diseases. Cham, Switzerland: Springer, 63-96. http://dx.doi.org/10.1007/978-3-319-24789-2 3

Kurtzman CP, Robnett CJ, 1997. Identification of clinically important ascomycetous yeasts based on nucleotide divergence in the $5^{\prime}$ end of the large-subunit (26S) ribosomal DNA gene. Journal of Clinical Microbiology 35, 1216-1223.

López GMA, Enríquez VO, 1980. Presencia de Monilia roreri Cif. et Par. en el cacao, Theobroma cacao L. en la frontera de Costa Rica, Nicaragua. Ministerio de Desarrollo Agropecuario, Managua, Nicaragua.

O'Donnell K, Cigelnik E, 1997. Two divergent intragenomic rDNA ITS2 types within a monophyletic lineage of the fungus Fusarium are nonorthologous. Molecular Phylogenetics and Evolution 7, 103-116. http://dx.doi.org/10.1006/mpev.1996.0376

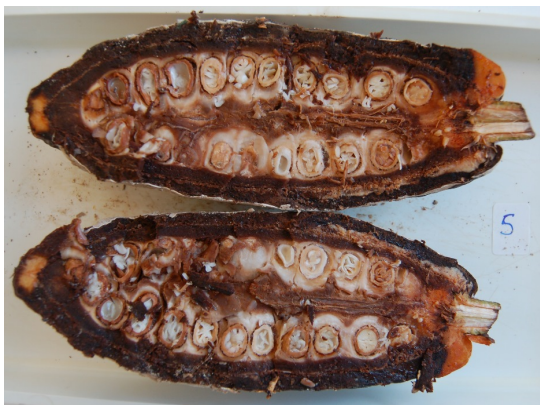

Figure 2 